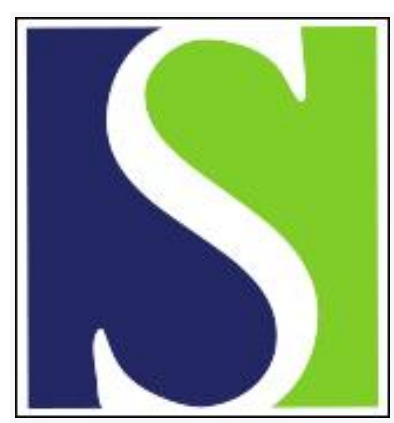

Scand J Work Environ Health 1994;20(2):101-106

https://doi.org/10.5271/sjweh.1425

Issue date: 01 Apr 1994

Seven-year follow-up of white-finger symptoms and radiographic wrist findings in lumberjacks and referents.

by Kivekas J, Riihimaki H, Husman K, Hanninen K, Harkonen H, Kuusela T, Pekkarinen M, Tola S, Zitting AJ

Affiliation: LEL Employment Pension Fund, Helsinki, Finland.

The following article refers to this text: 2014;40(2):133-145

This article in PubMed: www.ncbi.nlm.nih.gov/pubmed/8079130

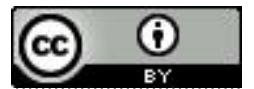




\title{
Seven-year follow-up of white-finger symptoms and radiographic wrist findings in lumberjacks and referents
}

\author{
by Jukka Kivekäs, MD, ${ }^{1}$ Hilkka Riihimäki, MD, ${ }^{2}$ Kaj Husman, MD, ${ }^{3}$ Kari Hänninen, MSc(Eng), ${ }^{1}$ \\ Hannu Härkönen, MD, ${ }^{4}$ Timo Kuusela, MD, ${ }^{2}$ Matti Pekkarinen, MD, ${ }^{2}$ Sakari Tola, MD, ${ }^{4}$ \\ Anders $\mathrm{J}$ Zitting, MD²
}

KIVEKÄS J, RIIHIMÄKI H, HUSMAN K, HÄNNINEN K, HÄRKÖNEN H, KUUSELA T, PEKKARINEN M, TOLA S, ZITTING AJ. Seven-year follow-up of white-finger symptoms and radiographic wrist findings in lumberjacks and referents. Scand J Work Environ Health 1994;20:101-6.

\begin{abstract}
OrJectives - In 1978, a cross-sectional study of 279 lumberjacks exposed to hand-arm vibration and 178 unexposed referents was conducted. The aim of the present study was to provide a sevenyear follow-up on (i) the changes in the white-finger symptoms among the lumberjacks and the referents, (ii) the effect of white-finger symptoms on the professional prognosis of the lumberjacks, and (iii) the relationship between hand-arm vibration and changes in wrist bones.

Methods - The methods consisted of a questionnaire, a routine clinical examination, and radiographs of the wrists and hands. The examinations were conducted as a field study using a mobile unit.

RESULTs - The prevalence of white-finger symptoms was $18 \%$ among the lumberjacks and $3 \%$ among the referents in the original study. Seven years later 213 lumberjacks and 140 referents participated in the follow-up. The prevalence of white-finger symptoms was 24.9 among the lumberjacks and 5.7 among the referents, and the seven-year cumulative incidence was $14.7 \%$ among the lumberjacks and $2.3 \%$ among the referents. After allowance for age, there was no difference in the incidence of whitefinger symptoms between the lumberjacks with fewer than 15 years of exposure and the referents, but the risk increased with increasing duration of exposure (risk ratio $8.9,95 \%$ confidence interval 2.5 28.9 for those exposed at least 25 years). There was no difference between the two groups in the prevalence of radiographically detectable translucencies or osteoarthrotic changes in the wrists and hands. Conclusions - According to the results, white-finger symptoms are still a problem among lumberjacks who started chain-saw work before 1970.
\end{abstract}

KEY TERMS - hand-arm vibration, longitudinal study, lunatomalacia, osteoarthrosis, radiographic translucencies.

Chain-saw vibration can cause white-finger symptoms. It has been claimed that it also causes radiographically detectable translucencies in the carpal bones of exposed workers $(1-3)$, but the results of various studies have been controversial (4-6).

The prevalence of white-finger symptoms among Finnish lumberjacks was at its highest in the early 1970 s, when it was $40-60 \%(7,8)$. During the 1970 s, the prevalence decreased, and in studies conducted at the end of the decade, it was $13-18 \%$ $(6,9)$.

In 1978 we studied 279 lumberjacks whose mean exposure time to chain-saw vibration was 10.4 years (6). One hundred and seventy-eight peat workers who were not exposed to hand-arm vibration served as the reference group. The prevalence of white-finger

1 LEL Employment Pension Fund, Helsinki, Finland.

2 Finnish Institute of Occupational Health, Helsinki, Finland.

3 Kuopio Regional Institute of Occupational Health, Kuopio, Finland.

4 Department of Public Health, Helsinki University, Helsinki, Finland.

Reprint requests to: Dr J Kivekäs, LEL Employment Pension Fund, PO Box 20, FIN-00241 Helsinki, Finland. symptoms was $18 \%$ among the lumberjacks and 3\% among the referents, respectively. The overall prevalence of circumscribed translucencies in the wrist bones of the lumberjacks was $9 \%$ for each hand. In the reference group, the respective prevalences were 8 and $9 \%$. The prevalence of bone translucencies was not related to either the duration of exposure or the occurrence of white-finger symptoms.

In 1985 we conducted a follow-up study of the same groups. The objective was to study (i) the changes in white-finger symptoms among the lumberjacks and the referents, (ii) the effect of whitefinger symptoms on the professional prognosis of the lumberjacks, and (iii) the relationship between handarm vibration and changes in wrist bones.

\section{Subjects and methods}

\section{Subjects}

In the follow-up phase, 213 lumberjacks (76\% of the original group) and 140 referents (78\% of the original group) were examined. Those 46 lumberjacks who had left their previous occupation during the follow-up period were included. The prevalence of white-finger symptoms in 1978 was slightly lower 
(17 versus 18\%) for the lumberjacks and higher ( 5 versus $3 \%$ ) for the referents who participated in the follow-up study as compared with the original groups.

At the end of the follow-up, the mean age of the lumberjacks was 41.9 (SD 9.2) years and that of the referents was 39.7 (SD 8.9) years. The lumberjacks' mean exposure time to hand-arm vibration was 19.7 (SD 12.4) years, with a range of $8-35$ years. Data on exposure were not obtained for four lumberjacks.

Peat workers drive a tractor full-time during the harvesting season ( $3-5$ months per year), and during the winter they mainly do maintenance and repair work. Referents exposed to chain-saw vibration for more than one year had been excluded from the study in 1978.

\section{Methods}

The study program consisted of a questionnaire, a routine clinical examination and radiographs of the wrists and hands. The examinations were conducted as a field study using a mobile unit as in the previous study.

The survey included questions on work history, general state of health, and symptoms of white fingers. Most of the questions were the same as in the previous study. The answers were checked for completeness. The prevalence of white-finger symptoms was estimated on the basis of the answers to the question "Have you had finger blanching?"

Because of technical difficulties, radiographs of the hands and wrists were obtained from only 188 lumberjacks and 126 referents in 1985.

The occurrence of circumscribed translucencies in the wrist bones was determined from the radiographs taken in 1978 and 1985 . The films were read independently by two radiologists who did not know the subject's age, occupation, or when the films were taken. In cases of discrepant classifications, joint rereadings were made. The agreement rate of the first interpretation was $82 \%$. The size and shape (regular or irregular) of the translucencies, as well as the possible sclerosis of their borders, were registered.

The degree of osteoarthrotic changes in the joints of the hand and wrist bones was classified according to Kellgren \& Lawrence (10) on the basis of reference radiographs. According to this classification,

Table 1. White-finger symptoms among the lumberjacks and referents in 1978 and 1985.

\begin{tabular}{ccccc}
\hline Year & \multicolumn{2}{c}{$\begin{array}{c}\text { White-finger } \\
\text { symptoms }\end{array}$} & & Risk \\
\cline { 2 - 4 } & $\begin{array}{c}\text { Lumber- } \\
\text { jacks } \\
(\mathrm{N}=213) \\
(\%)\end{array}$ & $\begin{array}{c}\text { Referents } \\
(\mathrm{N}=140) \\
(\%)\end{array}$ & $\begin{array}{c}95 \% \\
\text { ratio }\end{array}$ & $\begin{array}{c}95 \% \\
\text { confidence } \\
\text { interval }\end{array}$ \\
\hline 1978 & 16.9 & 5.0 & 3.4 & $1.7-6.9$ \\
1985 & 24.9 & 5.7 & 4.4 & $2.3-8.1$ \\
\hline
\end{tabular}

the findings were registered on a five-point scale (none, possible, mild, moderate, severe) for each joint. In the analysis, the occurrence of mild, moderate, or severe osteoarthrosis was considered osteoarthrosis.

\section{Data analysis}

Separate analyses were conducted for the prevalence data and the seven-year cumulative incidence data (first-time events). Cumulative incidence was approximated as the proportion of those who had contracted white-finger symptoms of those previously symptomless. In the stratified analysis, risk ratios (RR) and 95\% confidence intervals $(95 \% \mathrm{CI}$ ) (based on the standard errors) were estimated (11). The test for trend in proportions was analyzed according to Nurminen (12).

\section{Results}

\section{Prevalence of white-finger symptoms}

In the beginning of the follow-up, the prevalence of white-finger symptoms was higher among the lumberjacks than among the referents. There was a significant increase in the lumberjacks' prevalence, whereas no change was found for the referents (table 1).

White-finger symptoms were rare among the men younger than 37 years of age; the risk was five- to sixfold in the two older age groups (table 2). After allowance for age, there was a significant trend for the prevalence of white-finger symptoms according to the duration of exposure (chi square 30.6, $\mathrm{P}<0.001$ ). The risk ratio for at least 25 years of exposure was $6.8(95 \%$ CI $3.0-15.8)$.

\section{Incidence of white-finger symptoms}

The seven-year cumulative incidence of white-finger symptoms was $14.7 \%$ among the lumberjacks and $2.3 \%$ among the referents $\left(\mathrm{RR}_{\text {crude }} 6.5,95 \% \mathrm{CI} 2.4\right.$ 17.5). For the 23 new cases of white-finger symptoms among the lumberjacks the mean exposure time from the onset of exposure to the beginning of symptoms was 17.5 (SD 2.8, range 13-25) years.

The incidence was highest in the middle-age group (table 3). After allowance for age, there was a significant increasing trend in the incidence of whitefinger symptoms according to the duration of exposure (chi square $16.6, \mathrm{P}<0.001$ ). The risk ratio for at least 25 years of exposure was 8.9 (95\% CI $2.5-$ 28.9).

White-finger symptoms developed in only one previously asymptomatic lumberjack younger than 37 years and one exposed for less than 15 years. The number of lumberjacks who reported white-finger symptoms in 1978 was 78 , and 72 of the 78 reported white-finger symptoms also in 1985 . Five of the six "recovered" lumberjacks had reported white-finger symptoms only in one hand in 1978. 
Table 2. White-finger symptoms according to duration of exposure to chain-saw vibration and age in 1985 . (A=all subjects in the exposure category, $\mathrm{B}=$ number of subjects with white-finger symptoms, $95 \% \mathrm{Cl}=95 \%$ confidence interval)

\begin{tabular}{|c|c|c|c|c|c|c|c|c|c|c|c|c|}
\hline \multirow{3}{*}{$\begin{array}{l}\text { Age group } \\
\text { (years) }\end{array}$} & \multicolumn{10}{|c|}{ Duration of exposure } & \multirow{3}{*}{$\begin{array}{l}\text { Risk } \\
\text { ratio }\end{array}$} & \multirow{3}{*}{$95 \% \mathrm{Cl}$} \\
\hline & \multicolumn{2}{|c|}{0 years $^{a}$} & \multicolumn{2}{|c|}{$8-14$ years } & \multicolumn{2}{|c|}{$15-24$ years } & \multicolumn{2}{|c|}{$25-35$ years } & \multicolumn{2}{|c|}{ Total } & & \\
\hline & A & B & A & B & A & B & A & B & A & B & & \\
\hline $\begin{array}{l}25-36 \\
37-46 \\
47-61\end{array}$ & $\begin{array}{l}67 \\
32 \\
41 \\
\end{array}$ & $\begin{array}{l}2 \\
4 \\
2 \\
\end{array}$ & $\begin{array}{r}46 \\
10 \\
8\end{array}$ & $\begin{array}{l}2 \\
1 \\
0\end{array}$ & $\begin{array}{l}23 \\
44 \\
29\end{array}$ & $\begin{array}{r}2 \\
13 \\
11 \\
\end{array}$ & $\begin{array}{r}0 \\
14 \\
35 \\
\end{array}$ & $\begin{array}{r}0 \\
11 \\
13 \\
\end{array}$ & $\begin{array}{l}136 \\
100 \\
113 \\
\end{array}$ & $\begin{array}{r}6(4.4 \%) \\
29(29.0 \%) \\
26(23.0 \%)\end{array}$ & $\begin{array}{l}1.00 \\
6.6 \\
5.2 \\
\end{array}$ & $\begin{array}{l}3.3-13.3 \\
2.5-11.0 \\
\end{array}$ \\
\hline $\begin{array}{l}\text { Total } \\
\%\end{array}$ & 140 & $\begin{array}{l}8 \\
5.7\end{array}$ & 64 & $\begin{array}{l}3 \\
4.7\end{array}$ & 96 & $\begin{array}{l}29 \\
27.1\end{array}$ & 49 & $\begin{array}{l}24 \\
49.0\end{array}$ & & & & \\
\hline \multicolumn{2}{|l|}{$\begin{array}{l}\text { Risk ratio } \\
95 \% \mathrm{Cl}\end{array}$} & 1.0 & & $\begin{array}{r}0.8 \\
-3.0\end{array}$ & & $\begin{array}{r}4.7 \\
2.4-9.2\end{array}$ & & $\begin{array}{r}8.6 \\
-15.7\end{array}$ & & & & \\
\hline \multicolumn{2}{|c|}{$\begin{array}{l}\text { Age-adjusted risk ratio } \\
95 \% \mathrm{Cl}\end{array}$} & 1.0 & & $\begin{array}{r}0.9 \\
-3.6\end{array}$ & & $\begin{array}{r}3.8 \\
1.7-7.7\end{array}$ & & $\begin{array}{r}6.8 \\
-15.8\end{array}$ & & & & \\
\hline
\end{tabular}

a Referents.

Table 3. First-time events of white finger symptoms in 1978-1985 among the lumberjacks and referents according to duration of exposure to chain-saw vibration and age. $(A=$ subjects without white-finger symptoms in $1978, B=$ subjects experiencing white-finger symptoms for first time between 1978 and $1985,95 \% \mathrm{Cl}=95 \%$ confidence interval)

\begin{tabular}{|c|c|c|c|c|c|c|c|c|c|c|c|c|}
\hline \multirow{3}{*}{$\begin{array}{l}\text { Age group } \\
\text { (years) }\end{array}$} & \multicolumn{10}{|c|}{ Duration of exposure } & \multirow{3}{*}{$\begin{array}{l}\text { Risk } \\
\text { ratio }\end{array}$} & \multirow{3}{*}{$95 \% \mathrm{Cl}$} \\
\hline & \multicolumn{2}{|c|}{0 years ${ }^{a}$} & \multicolumn{2}{|c|}{$8-14$ years } & \multicolumn{2}{|c|}{$15-24$ years } & \multicolumn{2}{|c|}{$25-35$ years } & \multicolumn{2}{|c|}{ Total } & & \\
\hline & A & $\mathrm{B}$ & A & B & A & $B$ & A & B & A & B & & \\
\hline $\begin{array}{l}25-36 \\
37-46 \\
47-61\end{array}$ & $\begin{array}{l}63 \\
29 \\
39 \\
\end{array}$ & $\begin{array}{l}0 \\
2 \\
1\end{array}$ & $\begin{array}{r}43 \\
10 \\
8\end{array}$ & $\begin{array}{l}0 \\
1 \\
0\end{array}$ & $\begin{array}{l}21 \\
33 \\
22\end{array}$ & $\begin{array}{l}1 \\
5 \\
5\end{array}$ & $\begin{array}{r}0 \\
10 \\
26 \\
\end{array}$ & $\begin{array}{l}0 \\
7 \\
4 \\
\end{array}$ & $\begin{array}{r}127 \\
82 \\
95 \\
\end{array}$ & $\begin{array}{r}1(0.8 \%) \\
15(18.3 \%) \\
10(10.5 \%) \\
\end{array}$ & $\begin{array}{l}1.00 \\
23.2 \\
13.4 \\
\end{array}$ & $\begin{array}{l}6.1-87.8 \\
2.9-62.3 \\
\end{array}$ \\
\hline $\begin{array}{l}\text { Total } \\
\%\end{array}$ & 131 & $\begin{array}{l}3 \\
2.3\end{array}$ & 61 & $\begin{array}{l}1 \\
1.6\end{array}$ & 76 & $\begin{array}{l}11 \\
14.5\end{array}$ & 36 & $\begin{array}{l}11 \\
30.6\end{array}$ & & & & \\
\hline \multicolumn{2}{|l|}{$\begin{array}{l}\text { Risk ratio } \\
95 \% \mathrm{Cl}\end{array}$} & 1.0 & & $\begin{array}{r}0.7 \\
-6.6\end{array}$ & & $\begin{array}{r}6.3 \\
-18.6\end{array}$ & & $\begin{array}{r}3.3 \\
-34.2\end{array}$ & & & & \\
\hline \multicolumn{2}{|c|}{$\begin{array}{l}\text { Age-adjusted risk ratio } \\
95 \% \mathrm{Cl}\end{array}$} & 1.0 & & $\begin{array}{r}1.1 \\
10.5\end{array}$ & & $\begin{array}{r}5.0 \\
-15.6\end{array}$ & & $\begin{array}{r}8.9 \\
-28.9\end{array}$ & & & & \\
\hline
\end{tabular}

a Referents.

\section{Radiographic findings}

There were no significant differences in the occurrence rates of translucencies in the wrist bones between the lumberjacks and the referents (table 4). The prevalence of translucencies increased as age increased.

Lunatomalacia was found in 1978 in three lumberjacks and in 1985 in four lumberjacks. Two of the four had previously injured the affected wrist. Among the referents, no one had lunatomalacia in 1978, and one had it in 1985.

The prevalence of osteoarthrosis of the hands and wrists increased from $5.3 \%$ in 1978 to $16.0 \%$ in 1985 among the lumberjacks and from 6.4 to $12.7 \%$ among the referents. There was no difference between the hands. In both groups there was a strong relationship between osteoarthrosis and age (table 5). After allowance for age, the prevalence of osteoarthrosis was not related to exposure time among the lumberjacks.

\section{Turnover of workers}

Of the 213 lumberjacks examined in 1985, 167 (78\%) had continued working as lumberjacks, 20 (9\%) had changed to another occupation, and 26
(12\%) had retired. Of the 140 referents examined, $135(96 \%)$ were still active in worklife.

White-finger symptoms in the beginning of the follow-up was not a significant predictor for selection out of occupation among the lumberjacks. Twentyfour of 36 lumberjacks with white-finger symptoms in 1978 were still working as lumberjacks in 1985 , four had changed occupations, and eight had retired. Likewise, there was no evidence for a relationship between the radiographically detectable translucencies in the wrist bones and turnover among the lumberjacks.

\section{Discussion}

According to this study, white-finger symptoms are still a problem for lumberjacks, at least among the older men exposed for a long time. The seven-year cumulative incidence of white-finger symptoms among the lumberjacks exposed for at least 25 years was as high as $30.6 \%$, and the prevalence at the end of the follow-up was $49.0 \%$. In a recent Japanese study the prevalence of white-finger symptoms among workers with a duration of exposure of 30 
Table 4. Radiographicaliy detectable translucencies in the wrists of the lumberjacks and referents in 1978 and 1985.

\begin{tabular}{|c|c|c|c|c|c|}
\hline \multirow{2}{*}{$\begin{array}{l}\text { Age group } \\
\text { in } 1985\end{array}$} & \multirow{2}{*}{$\begin{array}{l}\text { Subjects } \\
\text { in } 1985 \\
\text { (N) }\end{array}$} & \multicolumn{2}{|c|}{$\begin{array}{c}\text { Prevalence of } \\
\text { translucencies }(\%)\end{array}$} & \multirow{2}{*}{$\begin{array}{c}\text { Subjects without } \\
\text { translucencies } \\
\text { in } 1978 \\
\text { (N) }\end{array}$} & \multirow{2}{*}{$\begin{array}{c}\text { Seven-year } \\
\text { cumulative } \\
\text { incidence } \\
(\%)\end{array}$} \\
\hline & & 1978 & 1985 & & \\
\hline \multicolumn{6}{|l|}{ Lumberjacks } \\
\hline $\begin{array}{l}25-36 \text { years } \\
37-46 \text { years } \\
47-61 \text { years }\end{array}$ & $\begin{array}{l}64 \\
58 \\
66\end{array}$ & $\begin{array}{r}4.7 \\
17.2 \\
31.8\end{array}$ & $\begin{array}{r}6.3 \\
22.4 \\
33.3\end{array}$ & $\begin{array}{l}61 \\
48 \\
45\end{array}$ & $\begin{array}{l}1.6 \\
6.3 \\
2.2\end{array}$ \\
\hline All & 188 & 18.1 & 20.7 & 154 & 4.6 \\
\hline \multicolumn{6}{|l|}{ Referents } \\
\hline $\begin{array}{l}25-36 \text { years } \\
37-46 \text { years } \\
47-61 \text { years }\end{array}$ & $\begin{array}{l}59 \\
30 \\
37\end{array}$ & $\begin{array}{r}6.8 \\
10.0 \\
32.4\end{array}$ & $\begin{array}{l}11.9 \\
13.3 \\
37.8\end{array}$ & $\begin{array}{l}55 \\
27 \\
25\end{array}$ & $\begin{array}{l}5.5 \\
3.7 \\
8.0\end{array}$ \\
\hline All & 126 & 15.1 & 19.8 & 107 & 5.6 \\
\hline
\end{tabular}

Tabie 5. Radiographically detectable osteoarthrosis in the wrists and hands of the lumberjacks and referents in 1978 and 1985.

\begin{tabular}{|c|c|c|c|c|c|}
\hline \multirow{2}{*}{$\begin{array}{l}\text { Age group } \\
\text { in } 1985\end{array}$} & \multirow{2}{*}{$\begin{array}{l}\text { Subjects } \\
\text { in } 1985 \\
(N)\end{array}$} & \multicolumn{2}{|c|}{$\begin{array}{c}\text { Prevalence of } \\
\text { osteoarthrosis }(\%)\end{array}$} & \multirow{2}{*}{$\begin{array}{l}\text { Subjects without } \\
\text { osteoarthrosis } \\
\text { in } 1978 \\
\text { (N) }\end{array}$} & \multirow{2}{*}{$\begin{array}{c}\text { Seven-year } \\
\text { cumulative } \\
\text { incidence } \\
(\%)\end{array}$} \\
\hline & & 1978 & 1985 & & \\
\hline \multicolumn{6}{|l|}{ Lumberjacks } \\
\hline $\begin{array}{l}18-29 \text { years } \\
30-39 \text { years } \\
40-54 \text { years }\end{array}$ & $\begin{array}{l}64 \\
58 \\
66\end{array}$ & $\begin{array}{r}0 \\
1.7 \\
13.7\end{array}$ & $\begin{array}{r}3.1 \\
6.9 \\
36.4\end{array}$ & $\begin{array}{l}61 \\
57 \\
57\end{array}$ & $\begin{array}{r}3.1 \\
5.3 \\
26.3\end{array}$ \\
\hline All & 188 & 5.3 & 16.0 & 178 & 11.2 \\
\hline \multicolumn{6}{|l|}{ Referents } \\
\hline $\begin{array}{l}18-29 \text { years } \\
30-39 \text { years } \\
40-54 \text { years }\end{array}$ & $\begin{array}{l}59 \\
30 \\
37\end{array}$ & $\begin{array}{r}0 \\
6.7 \\
16.2\end{array}$ & $\begin{array}{r}0 \\
16.7 \\
29.7\end{array}$ & $\begin{array}{l}59 \\
28 \\
31\end{array}$ & $\begin{array}{r}0 \\
10.7 \\
16.1\end{array}$ \\
\hline All & 126 & 6.4 & 12.7 & 118 & 6.8 \\
\hline
\end{tabular}

years or more was $20.9 \%$ (13). In this study only one new case of white-finger symptoms occurred in the least-exposed group of lumberjacks, who started working with chain saws after 1970.

The differential participation in our follow-up study with regard to white-finger symptoms in 1978 among the two groups may have caused bias. This bias would tend to dilute the occupational effect and thus would not substantially influence the conclusions drawn from our study.

In our study, the prevalence and incidence of white-finger symptoms was determined from the workers' subjective reports of finger blanching without information on its origin or a specified period of observation. Thus there may have been some cases of finger blanching due to circulatory problems in both groups. The proportion of such cases was assumed to be similar in both groups. The same question concerning the last two years has been used in studies in which the prevalences of white-finger symptoms have been slightly smaller $(8,9)$. Our study was a prospective follow-up of workers with a long exposure history. The mean exposure time was 19.7 (range 8-35) years, which is eight years longer than in the aforementioned studies $(8,9)$, and this difference may explain the higher prevalence.

The prevalence of white-finger symptoms decreased during the 1970s, and the most important factor contributing to this decrease was the damping of chain-saw vibration. New chain-saw models that generate less vibration appeared in logging work in the late 1960s and early 1970s (14-17). In addition, the vibration measured from the wrists of lumberjacks has been lower with these third-generation chain saws.

In this study, there was a group of lumberjacks who only or mainly had used third-generation chain saws. Only one of these men reported symptoms of white-fingers at the end of the follow-up. In Japan, Futatsuka \& Ueno (18) found white-finger symptoms in only $1.6 \%$ of the lumberjacks who had been exposed for seven to eight years and had started using chain saws in 1972-1973. The mean exposure time until white-finger symptoms first occurred was 17.5 years among the new cases. This length of time is much longer than the four to five years reported in the early 1970 s (8).

It seems that white-finger symptoms develop much more slowly when modern saws are used instead of 
older ones. Among the lumberjacks with an exposure history of at least 15 years, however, the prevalence and incidence of white-finger symptoms increased with an increase in the duration of exposure. This finding indicates that the vibration of modern saws can elicit or maintain symptoms initiated by former exposure to more intense hand-arm vibration.

Two out of three of the lumberjacks who reported white-finger symptoms in 1978 were still in the same occupation in 1985. Most of them still had symptoms, but the symptoms were less severe. Typically, the symptoms appeared when the men's hands came into contact with cold and moist conditions, for instance, while fishing during leisure time.

There was no difference between the study and the reference groups in the prevalence of radiographically detectable translucencies in the wrist bones. The prevalence of translucencies increased as age increased in both groups.

The prior evidence for a connection between translucencies in the wrist bones and hand-arm vibration is based on studies made in the early $1970 \mathrm{~s}(1,2$, 19). The lumberjacks examined in these studies had a long history of working with the old, heavy chain saws, whose vibration was poorly damped.

A similar lack of correlation between hand-arm vibration and translucencies, as in this study, has been reported in many earlier studies (4-6). According to these studies, exposure to hand-arm vibration, at least with the modern type of chain saws, does not cause radiographically detectable translucencies in wrist bones.

In this study the prevalence of osteoarthrosis was greatly age-dependent, but it was not dependent on exposure to hand-arm vibration. In both groups, the prevalence was less than in the Finnish agricultural population (20). The determination of osteoarthrosis in this study was based only on radiographic changes in joints of the wrists and hands.

Findings on the connection between osteoarthrosis and physical load have been controversial. Gordon (21) and Zinn (22) found osteoarthrosis more often in farmers than in other populations. However, in many studies there has been no connection between the prevalence of osteoarthrosis and physical load (23-25) or vibration (26).

\section{Acknowledgments}

This study was financially supported by the Finnish Work Environment Fund.

\section{References}

1. Kumlin T, Wiikeri M, Sumari P. Radiological changes in carpal and metacarpal bones and phalanges caused by chain saw vibration. Br J Ind Med 1973; $30: 71-3$

2. Horwath F, Kakosy T. Aseptische Nekrosen und Handwurzelknochen von Motorsägearbeitern. Z Orthop 1973;111:906-13.
3. Suzuki K, Takahashi S, Nakagawa T. Radiological studies of the wrist joint among chain saw operating lumberjacks in Japan. Acta Orthop Scand 1978;49: 464-8.

4. James P, Yates J, Pearson J. An investigation of the prevalence of the bone cysts in hands exposed to vibration. In: Taylor W, Pelmear P, ed. Vibration white finger in industry. London: Academic Press, 1975: $43-51$.

5. Hellström B, Lange Andersen K. Vibration injuries in Norwegian forest workers. Br J Ind Med 1972;29: $255-63$.

6. Härkönen H, Riihimäki H, Tola $S$, Mattsson T, Zitting A, Husman K. Symptoms of vibration syndrome and radiographic findings in the wrists of lumberjacks. Br J Ind Med 1984;41:133-6.

7. Seppäläinen AM. Peripheral neuropathy in forest workers: a field study. Work Environ Health 1972; 9:106-11.

8. Pyykkö I, Sairanen E, Korhonen O, Färkkilä M, Hyvärinen $\mathbf{J}$. A decrease in the prevalence and severity of vibration-induced white fingers among lumberjacks in Finland. Scand J Work Environ Health 1978;4: $246-54$.

9. Pyykkö I, Korhonen O, Färkkilä M, Starck J, Aatola $S$, Jäntti V. Vibration syndrome among Finnish forest workers, a follow-up study from 1972 to 1983. Scand J Work Environ Health 1986;12:307-12.

10. Kellgren J, Lawrence S. Radiological assessment of osteoarthrosis. Ann Rheum Dis 1957;16:494-502.

11. Miettinen OS. Theoretical epidemiology: principles of occurrence research in medicine. New York, NY: Delmar Publishers, 1985:180-1.

12. Nurminen M. Analysis of trends in proportions with an ordinally scaled determinant. Biom J 1986;28: $965-974$.

13. Mirbod S, Yoshida H, Nagata C, Inaba R, Komuta Y, Iwata $\mathrm{H}$. Hand arm vibration syndrome and its prevalence in the present status private forestry enterprises in Japan. Int Arch Occup Environ Health 1992;64: 93-9.

14. Pyykkö I, Starck J, Färkkilä M, Hoikkala M, Korhonen $\mathrm{O}$, Nurminen $M$. Hand-arm vibration in the etiology of hearing loss in lumberjacks. Br J Ind Med 1981; 38:281-89.

15. Starck J, Aatola S, Hoikkala M, Färkkilä M, Korhonen $O$, Pyykkö I. Chain saw vibration: effects of age and repeatability of the measurements. In: Brammer AJ, Taylor W, ed. Vibration effects of the hand arm in industry. New York, NY: Wiley \& Sons, 1982: $197-202$.

16. Starck J. High impulse acceleration levels in hand-held vibratory tools: an additional factor in the hazards associated with the hand-arm vibration syndrome. Scand J Work Environ Health 1984;10:171-8.

17. Koskimies K, Pyykkö I, Starck J, Inaba R. Vibration syndrome among Finnish forest workers between 1972 and 1990. Int Arch Occup Environ Health 1992;64: $251-6$.

18. Futatsuka M, Ueno T. A follow-up study of vibrationinduced white finger due to chain-saw operation. Scand J Work Environ Health 1986;12:304-66.

19. Laitinen J, Puranen J, Vuorinen P. Vibration syndrome in lumbermen. J Occup Med 1974;16:552-6.

20. Kärkkäinen A.: Käden nivelrikko Suomen yli 30-vuotisessa väestössä [Osteoarthrosis of the hand in the Finnish population aged 30 years and over]. Turku (Finland): Social Insurance Institution, 1985. (Publications of the Social Insurance Institution; ML:52) (English summary.)

21. Gordon T. Osteoarthrosis in US adults. In: Bennet $P$, Wood $\mathrm{H}$, ed. Population studies of the rheumatic diseases: proceedings of the Third International Symposium, Amsterdam 1968. Amsterdam: Excerpta Medi- 
ca, 1968:391-7. (International congress series; no 148.)

22. Zinn W. Die Huftarthrose und ihre Beziehung zur Arthrose der Fingerendgelenke. Verh Dtsch Ges Rheumatol 1978;10:354-6.

23. McCracken W. Classification of degenerative arthritis. Can Med Assoc J 1978; 1 18:1 16.

24. Adams I. Osteoartrosis and sport. J R Soc Med 1979; $72: 185-7$.
25. Moretz J, Harlan S, Goodrich J, Walters R. Long-term follow-up of knee injuries in highschool football players. Am J Sports Med 1984;12:298-300.

26. Boyle J, Smith N, Burke F. Vibration white finger. J Hand Surg Br 1988;13:171-6.

Received for publication: 24 November 1992 